\title{
Kajian Sifat Tarik Serat Pelepah Lontar dengan Singular Fiber Tensile Testing Methode
}

\author{
Melsiani R F Saduk ${ }^{1)^{\star}}$, Fransisko Piri Niron ${ }^{2)}$ \\ 1) Jurusan Teknik Mesin Politeknik Negeri Kupang \\ Jalan. Adi Sucipto Po Box 139 Penfui Kupang. 85000 \\ Email: melsianisd@gmail.com \\ 2) Jurusan Teknik Mesin, Politeknik Negeri Kupang \\ Jalan. Adi Sucipto Po Box 139 Penfui Kupang. 85000 \\ Email: fransiskoniron@yahoo.co.id
}

doi: https://doi.org/10.24843/METTEK.2018.v04.i01.p02

\begin{abstract}
Abstrak
Penggunaan serat alam sebagai filler pada komposit mulai banyak digunakan. Salah satu yang memiliki prospek cukup baik adalah serat pelepah pohon lontar (Borassus Flabellifer), yang penggunaannya masih terbatas pada bahan bakar atau komponen tertentu dalam pembangunan rumah. Serat pelepah lontar yang dikombinasikan dengan polyester sebagai matriks dapat bermanfaat untuk alternatif pembuatan body kapal ikan. Akan tetapi data dan informasi ilmiah tentang sifat mekanis kekuatan tarik serat tunggal pelepah pohon lontar ini masih belum tersedia sehingga pemanfaatan serat pelepah lontar ini masih sangat terbatas khususnya dalam penggunaan sebagai penguat pada komposit. Penelitian ini bertujuan untuk mengetahui seberapa besar nilai kekuatan tarik yang dihasilkan serat pelepah lontar tanpa perlakuan alkali maupun melalui perlakuan alkali dengan menggunakan singular fiber tensile testing methode. Nilai kekuatan tarik yang dihasilkan serat lontar tanpa perlakuan alkali adalah $364,32 \mathrm{MPa}$, dan kekuatan tarik maksimal serat yang diberi perlakuan alkali adalah serat dengan waktu perlakuan 4 jam (240 menit) sebesar 496,75 MPa,
\end{abstract}

Kata kunci: pelepah lontar, kekuatan tarik, serat alam, singular fiber

\begin{abstract}
The use of natural fiber as a filler of composite is commonly used. One of the natural fibers that have quite a good prospect is the fiber from the midrib of palm tree (Borassus Flabellifer), which its usage is limited on fuel or certain components in constructing houses. Fiber from the midrib of palm tree that combined with polyester as a matrix can be beneficial to be an alternative in constructing the body of boat for fishing. However, data and scientific information about the mechanic system of the tensile strength of the singular fiber of palm tree is very limited in particular in the utilization as strengthener on the composite. This research is to find out how strong the tensile strength created by palm fiber without treatment either with alkali or alkali with singular fiber tensile testing method. The value of tensile strength generated by palm fiber without alkali treatment is $364.32 \mathrm{Mpa}$, and the maximum tensile strength of the fiber with alkali treatment is the fiber with 4 hours (240 minutes) treatment amounts $496.74 \mathrm{Mpa}$.
\end{abstract}

Keywords: Midrib of palm, tensile strenght, singular fiber

Penulis Korespodensi, HP: 08123798137

Email: melsianisd@gmail.com 


\section{PENDAHULUAN}

Lontar (Borassus Flabellifer) adalah jenis palma yang bersifat serba guna. Hal ini disebabkan karena hampir semua bagian tumbuhan ini bermanfaat bagi umat manusia, antara lain sebagai bahan pangan, bangunan, perabot rumah tangga dan barang kesenian, akan tetapi yang banyak diusahakan oleh masyarakat dari pohon lontar adalah nira dan daun. Nira disadap sebagai minuman atau diolah menjadi gula. Daun lontar digunakan sebagai atap atau dianyam sebagai bahan kerajinan. Sedangkan batang lontar belum banyak dimanfaatkan, kecuali digunakan sebagai bahan bakar atau komponen tertentu dalam pembangunan rumah. Produk utama dari pengolahan tanaman lontar adalah nira segar, gula cair, gula merah/lempeng, dan gula semut. (Mahmud dan Amrizal,1991)

Lutony (1993) mengatakan bahwa tanaman lontar masih merupakan salah satu jenis flora di Indonesia yang belum dimanfaatkan secara optimal. Padahal populasi tanaman ini tersebar pada berbagai propinsi di Indonesia. Berbagai hasil studi menunjukkan bahwa masih cukup banyak kemungkinan untuk mengembangkan bagian-bagian tanaman lontar seperti batang pelepah lontar yang pemanfaatannya masih terbatas. Pada penelitian ini akan diambil serat dari pelepah lontar yang dapat menjadi alternatif bahan baku komposit.

Penelitian tentang komposit berbasis serat sangat beragam. Mulai dari variasi jenis matrik dan serat, jenis anyaman hingga bahan dasar matrik maupun serat. Penelitian juga berkembang dengan penggunaan bahan serat alam untuk beberapa variasi matrik sintetis dan alami. Komposit dengan penguat serat alam ini semakin intensif dikembangkan. Ini berkaitan dengan meluasnya penggunaan komposit pada berbagai bidang kehidupan serta tuntutan penggunaan material yang murah, ringan, sifat mekanik yang kuat dan tidak korosif, sehingga dapat menjadi bahan alternatif selain logam. Mulai dari yang sederhana seperti alat-alat rumah tangga sampai sektor industri baik industri skala kecil maupun industri skala besar seperti dalam industri pesawat terbang, otomotif, maupun untuk alat-alat olah raga (Imra, 2009; Budinski, 1995).

Keuntungan mendasar yang dimiliki oleh serat alam adalah murah, mudah didapat dan juga sangat berlimpah. Dari segi ketersediaan bahan baku serat alam, di propinsi Nusa Tenggara Timur memiliki tanaman pohon lontar yang cukup melimpah. Perkiraan populasi pohon lontar di Indonesia, (Mahmud $d k k$., 1991) yaitu di Nusa Tenggara Timur 4.407.000 pohon, Jawa Timur 5.000.000 pohon dan Sulawesi Selatan (hanya kabupaten Jeneponto) 300.000 pohon. Di Nusa tenggara Timur pohon lontar banyak dijumpai di pulau Sabu, Rote, Timor ,Flores, pesisir timur dan pesisir selatan pulau Sumba dan di Jawa Timur. Populasi lontar paling banyak terdapat di sekitar pulau Madura, dan tumbuh pula di sekitar pantai utara pulau Jawa (Lutony, 1993). Dari populasi lontar yang ada di NTT, baru sekitar $25 \%$ yang disadap untuk kebutuhan konsumsi lokal maupun sebagai bahan baku industri rumah tangga (Joseph $d k k$., 1990). Karena itu salah satu usaha untuk meningkatkan kegunaan pohon lontar adalah memanfaatkan pelepah lontar sebagai bahan baku komposit yang dapat diaplikasikan pada berbagai industri seperti industri pesawat terbang, otomotif, bangunan maupun untuk alat-alat olah raga. Penelitian ini bertujuan untuk mengetahui seberapa besar nilai kekuatan tarik yang dihasilkan serat pelepah lontar tanpa perlakuan alkali maupun melalui perlakuan alkali dengan menggunakan singular fiber tensile testing methode. Arah dan aplikasi dari penelitian ini adalah untuk mendapatkan material baru yang nantinya dapat bermanfaat sebagai alternatif untuk pembuatan body kapal penangkap ikan nelayan.

\section{METODE}

\subsection{Prosedur Penelitian}

\section{A. Penyiapan Serat}

Untuk mendapatkan serat yang siap digunakan sebagai penguat pada komposit, dilakukan beberapa tahapan berikut: 
1. Pelepah lontar sebelum diambil seratnya, direndam selama satu hari (24 jam) untuk memudahkan proses pengambilan serat

2. Kulit pelepah lontar dibuang atau dilepaskan

3. kemudian diambil serat bagian dalam dari pelepah lontar tersebut, dengan cara memotong bagian atas pelepah dan ditarik dengan tangan, hal ini dilakukan untuk menjaga serat agar tidak cacat.

4. Serat dipotong sesuai dengan standar yang ditetapkan

\section{B. Perlakuan Alkali Serat}

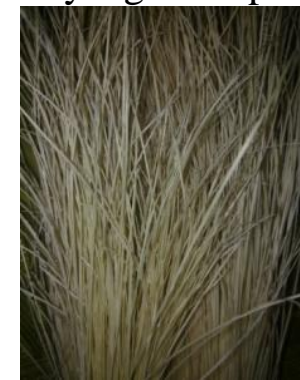

Gambar 1. serat pelepah lontar

Serat pelepah lontar kemudian diberi dilakukan perlakuan alkali (Alkali treatment) dengan cara di rendam. Larutan yang digunakan yaitu $\mathrm{NaOH} 5 \%$ per liter aquades dengan variasi lama waktu perendaman 30 menit, 60 menit, 90 menit, 120 menit, 150 menit, 180 menit, 210 menit, 240 menit, 270 menit dan 300 menit. Proses perendaman dapat dilihat pada gambar 2 di bawah ini.

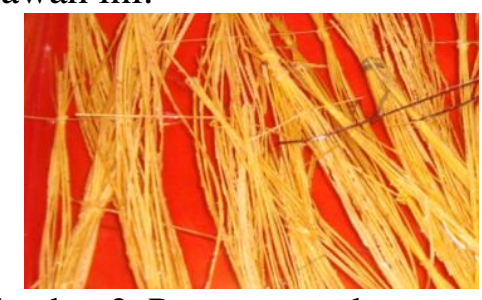

Gambar 2. Proses perendaman serat

Perendaman (alkalisasi) bertujuan untuk memodifikasi sifat permukaan secara kimiawi sehingga memperbaiki ikatan resin dan fiber, dimana perendaman dalam larutan alkali akan mengurangi hemicelluloses dan lignin pada serat alam (Vallo, 2004). Kemudian di cuci dengan air mengalir selama \pm 15 menit, dan dikeringkan selama \pm 12 jam.

\subsection{Kekuatan Tarik Serat Tunggal Pelepah Lontar}

Kekuatan serat tunggal dapat dihitung dengan persamaan rumus

$$
P=\sigma . A \text { atau } \sigma=F / A
$$

dengan:

$P=$ beban $(\mathrm{N})$

$A=$ luas penampang $\left(\mathrm{mm}^{2}\right)$

$\sigma=$ tegangan (MPa).

Besarnya regangan adalah jumlah pertambahan panjang karena pembebanan dibandingkan dengan panjang daerah ukur. Nilai regangan ini adalah regangan proporsional yang didapat dari garis. Proporsional pada grafik tegangan-tegangan hasil uji tarik komposit.(Surdia, 1995)

$$
C=\frac{\Delta L_{0}}{L_{0}}
$$

dengan:

$\epsilon=$ Regangan

$\Delta L=$ Pertambahan panjang $(\mathrm{mm})$

$L o=$ Panjang daerah ukur $(\mathrm{mm})$ 
Pada daerah proporsional yaitu daerah dimana tegangan-regangan yang terjadi masih sebanding, defleksi yang terjadi masih bersifat elastis dan masih berlaku hukum Hooke. Besarnya nilai modulus elastisitas yang juga merupakan perbandingan antara tegangan dan regangan pada daerah proporsional dapat dihitung dengan persamaan (Surdia, 1995)

$$
E=\frac{\sigma}{\varepsilon}
$$

dengan:

$E=$ Modulus elastisitas tarik (MPa)

$\sigma=$ Kekuatan tarik (MPa)

$\epsilon \quad=$ Regangan $(\mathrm{mm} / \mathrm{mm})$

\section{HASIL DAN PEMBAHASAN}

\subsection{Data Hasil Pengujian Kekuatan Tarik Serat Pelepah Lontar}

Serat pelepah lontar yang akan digunakan sebagai penguat pada komposit polyester, sebelumnya harus dilakukan pengujian kekuatan tarik baik untuk serat pelepah lontar tanpa perlakuan alkali maupun serat pelepah lontar dengan perlakuan alkali 5\% $\mathrm{NaOH}$. Perlakuan alkali $5 \% \mathrm{NaOH}$ terhadat serat pelepah lontar dimaksudkan untuk meningkatan kekuatan tarik serat dan meningkatkan interface antara serat dan matriks sehingga ikatan antar serat dan matriks menjadi kuat. Untuk itu dalam penelitian ini, serat diberi perlakuan alkali $5 \% \mathrm{NaOH}$ dengan lama waktu perlakuan 0 menit sampai 300 menit, dengan peningkatan setiap 30 menit.

Setelah itu baik serat tanpa perlakuan maupun serat yang diberi perlakuan alkali, diuji kekuatan tarik dengan menggunakan mesin uji tarik IMADA di Lab Fisika Universitas Brawijaya Malang

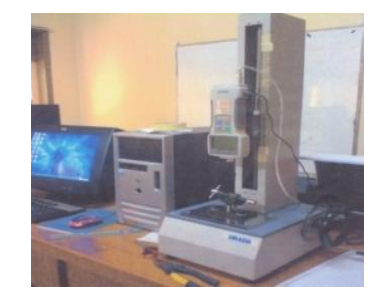

Gambar 3. Mesin Uji tarik serat Merk IMADA

Laboratorium Material MIPA Fisika Universitas Brawijaya

Sedangkan proses pengolahan data untuk pengujian kekuatan tarik serat pelepah lontar tanpa Perlakuan (0 menit) dan melalui perlakuan alkali 5\% NaOH selama 30 menit, 60 menit, 90 menit, 120 menit,150 menit, 180 menit, 210 menit, 240 menit, 270 menit dan 300 menit dapat dilihat pada tabel 1 di bawah ini. 
Tabel 1 Data Hasil Uji Tarik Serat Pelepah Lontar

\begin{tabular}{|c|c|c|c|c|c|c|c|c|}
\hline NO & $\begin{array}{c}\text { Waktu } \\
\text { Perendaman } \\
\text { Serat Alkali 5\% } \\
\text { NaOH (menit) }\end{array}$ & $\mathbf{F}(\mathbf{N})$ & $\begin{array}{c}\mathbf{A} \\
\left(\mathbf{m m}^{2}\right)\end{array}$ & $\begin{array}{c}\mathbf{L}_{\mathbf{0}} \\
(\mathbf{m m})\end{array}$ & $\mathbf{L}_{\mathbf{t}}(\mathbf{m m})$ & $\begin{array}{c}\mathbf{\sigma} \\
\mathbf{m a k s} \\
(\mathbf{M P a})\end{array}$ & $\mathbf{\varepsilon ( \% )}$ & $\mathbf{E} \mathbf{( M P a )}$ \\
\hline 1 & 0 & 33,21 & 0,091 & 100 & 109,00 & 364,32 & 9,00 & 4504,62 \\
\hline 2 & 30 & 21,37 & 0,056 & 100 & 110,70 & 379,21 & 10,70 & 4537,61 \\
\hline 2 & 60 & 18,02 & 0,047 & 100 & 110,80 & 380,27 & 10,80 & 6739,76 \\
\hline 4 & 90 & 19,98 & 0,053 & 100 & 110,00 & 380,33 & 10,00 & 8333,70 \\
\hline 5 & 120 & 18,02 & 0,047 & 100 & 109,60 & 381,21 & 9,60 & 5365,82 \\
\hline 6 & 150 & 20,73 & 0,053 & 100 & 107,30 & 390,01 & 7,30 & 9133,05 \\
\hline 7 & 180 & 19,59 & 0,050 & 100 & 105,40 & 393,25 & 5,40 & 13453,35 \\
\hline 8 & 210 & 18,59 & 0,047 & 100 & 106,00 & 393,53 & 6,00 & 8694,37 \\
\hline 9 & 240 & 22,47 & 0,045 & 100 & 105,80 & $\mathbf{4 9 6 , 7 5}$ & $\mathbf{6 , 0 0}$ & $\mathbf{1 8 3 3 9 , 4 5}$ \\
\hline 10 & 270 & 24,23 & 0,055 & 100 & 104,40 & 438,71 & 4,40 & 13728,35 \\
\hline 11 & 300 & 18,31 & 0,043 & 100 & 106,20 & 424,48 & 6,20 & 7328,91 \\
\hline
\end{tabular}

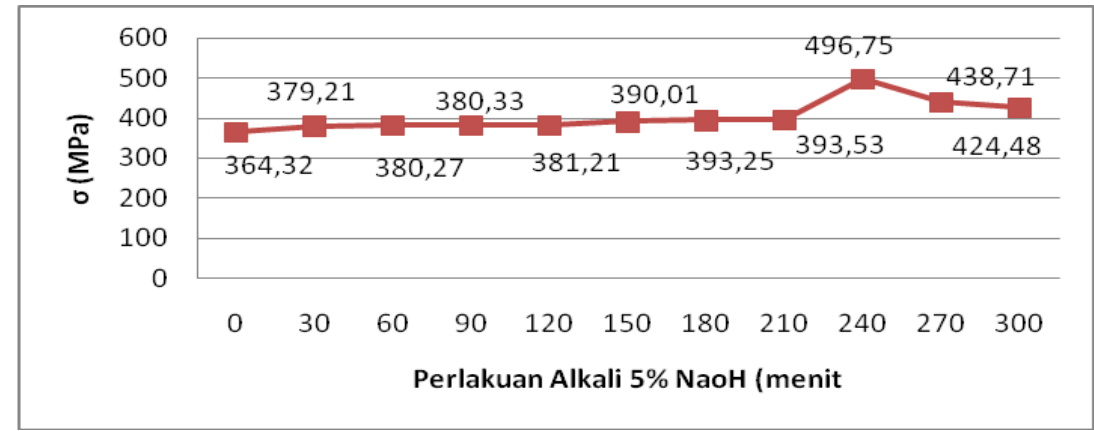

Gambar 4 Grafik Tegangan Tarik vs Perlakuan Alkali 5\% NaOH

Berdasarkan data hasil pengujian kekuatan tarik serat pada Tabel 1 dan gambar 4 di atas kekuatan tarik yang paling maksimum dimiliki oleh serat pelepah lontar dengan perlakuan alkali 240 menit. Hal ini menunjukkan bahwa perlakuan 5\% $\mathrm{NaOH}$ merupakan perlakuan yang paling efektif untuk meningkatkan kekuatan tarik serat pelepah lontar.

Perlakuan $\mathrm{NaOH}$ ini bertujuan untuk melarutkan lapisan yang menyerupai lilin di permukaan serat, seperti lignin, hemiselulosa, dan kotoran lainnya. Dengan hilangnya lapisan lilin ini, jika serat pelepah lontar ini nantinya digunakan sebagai penguat pada komposit maka ikatan antara serat dan matrik menjadi lebih kuat, sehingga kekuatan tarik komposit menjadi lebih tinggi. Namun, perlakuan $\mathrm{NaOH}$ yang lebih lama dapat menyebabkan kerusakan pada unsur selulosa. selulosa ialah komponen utama dinding sel tumbuhan. Selulosa bersifat seperti serabut, liat, tidak larut di dalam air, dan ditemukan terutama pada tangkai, batang, dahan, dan semua bagian berkayu dari jaringan tumbuhan.

Selulosa $\left(\mathrm{C}_{6} \mathrm{H}_{10} \mathrm{O}_{5}\right)$ n ialah karbohidrat utama yang disintesis oleh tanaman dan menempati hampir 50\% komponen penyusun struktur tanaman yang merupakan penyusun utama dari dinding sel seperti terlihat pada gambar 5 di bawah ini. 


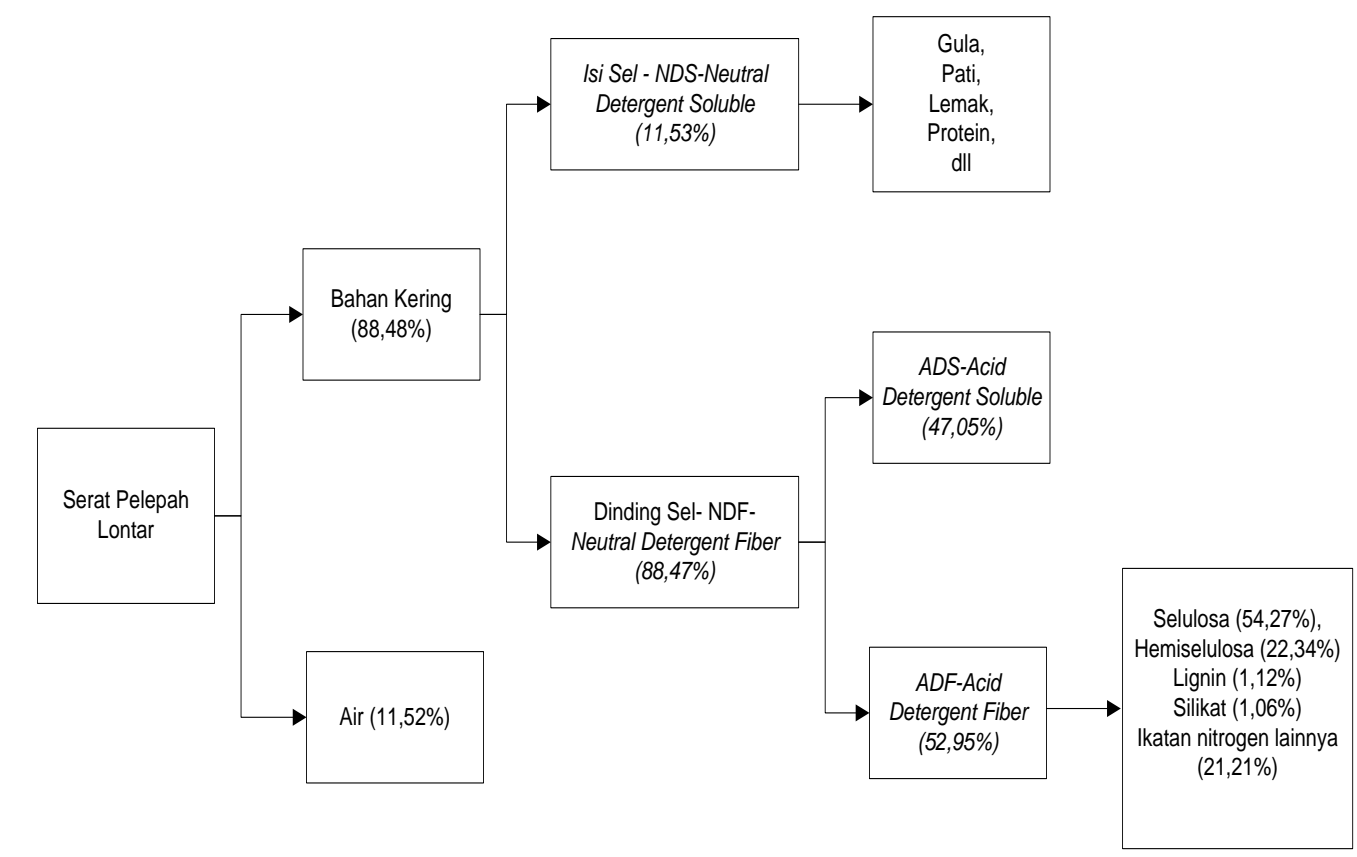

Gambar 5 Komposisi Kimia Serat Pelepah Lontar Berdasarkan Presentase Bahan Kering

\section{Keterangan :}

NDS $\quad=$ Neutral Detergent Soluble, Isi Sel (Larut Dalam Air)

NDF = Neutral Detergent Fiber, Dinding Sel (Tidak Larut Dalam Air)

$\mathrm{ADS} \quad=$ Acid Detergent Soluble

$\mathrm{ADF} \quad=$ Acid Detergent Fiber

Tabel 2 Kandungan Kimia Serat cPelepah Lontar

\begin{tabular}{ccc}
\hline No & Jenis Kandungan Kimia & $\begin{array}{c}\text { Presentase } \\
\text { bahan kering }(\boldsymbol{\%})\end{array}$ \\
\hline 1 & Bahan Kering & 88,48 \\
\hline 2 & NDF & 88,87 \\
\hline 3 & ADF & 52,95 \\
\hline 4 & Hemiselulosa & 22,34 \\
\hline 5 & Selulosa & 54,27 \\
\hline 6 & Silikat & 1,06 \\
\hline 7 & Lignin & 1,12 \\
\hline & Sumber $:$ Fakultas Peternakan Jurusan Nutrisi dan Makanan Ternak
\end{tabular}

Universitas Brawijaya.

Selulosa menyebabkan tubuh tumbuhan kaku yang disebabkan adanya ikatan hidrogen dalam penyusunanannya. Selulosa hampir ditemui di seluruh bagian tumbuhan karena merupakan penyusun utama dari dinding sel tumbuhan. Selulosa dibentuk oleh tanaman dengan menghubungkan banyak glukosa bersama-sama dan akhirnya membentuk molekul panjang yang digunakan untuk membangun dinding sel tanaman. (Dana George,2010) Karena itu jika perlakuan alkali yang terlalu lama pada serat akan menghilangkan sejumlah lignin, lilin dan minyak pada permukaan dinding serat, sehingga terjadi depolimerisasi pada selulosa dan membuat serat (molekul) lebih pendek. Sehingga akan merusak struktur selulosa, akibatnya, serat yang dikenai perlakuan alkali terlalu lama mengalami penurunan kekuatan tarik. Sebagai akibatnya, serat lontar dengan perlakuan alkali yang melebihi 4 jam (240 menit) memiliki kekuatan tarik yang lebih rendah.

Pada gambar 5 di bawah ini menunjukkan bahwa modulus elastisitas serat pelepah lontar yang diberi perlakuan $5 \% \mathrm{NaOH}$ mengalami peningkatan pada waktu perendaman serat selama 240 menit dan setelah lebih dari 240 menit maka terjadi penurunan modulus elastisitas. 


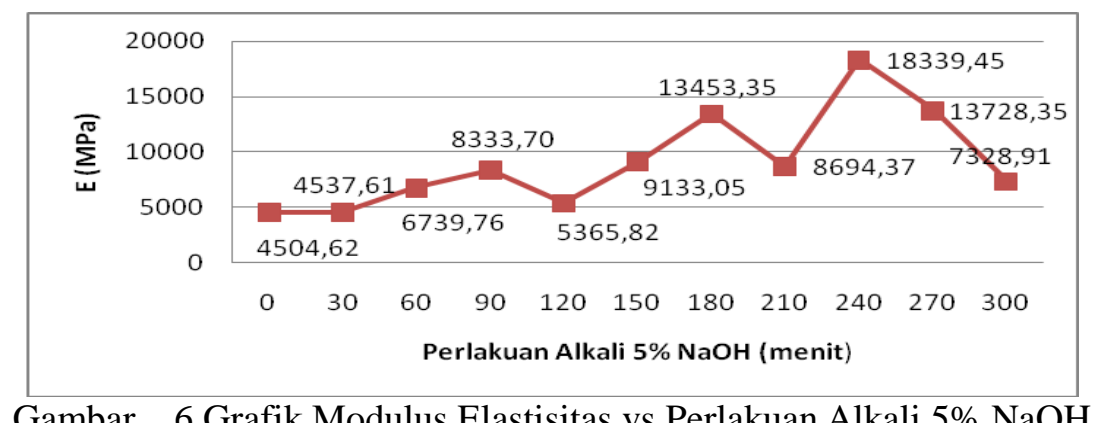

Sedangkan Pada gambar 6. di bawah ini terlihat bahwa jika perlakuan $\mathrm{NaOH}$ terlalu lama maka regangan mengalami penurunan. Meskipun pada titik tertentu terlihat ada peningkatan tetapi secara umum trendnya cenderung menurun

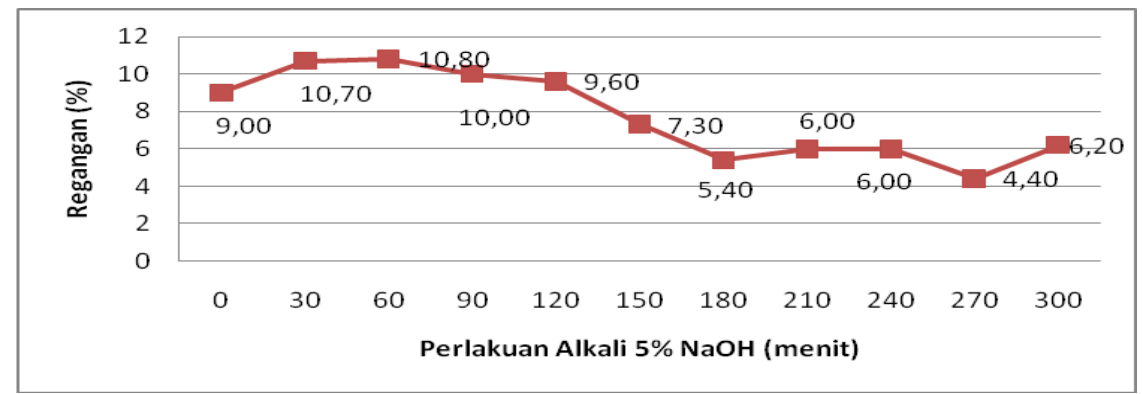

Gambar 6. Grafik Regangan Tarik vs Perlakuan Alkali 5\% NaOH

Kemudian untuk mengetahui pengaruh lama perlakuan alkali dengan waktu perlakuan antara 0 menit sampai 300 menit terhadap kekuatan tarik serat pelepah lontar maka dilakukan analisis statistik anova satu arah seperti pada tabel 3 di bawah ini.

Tabel 3. Hasil Analisis Varian (ANOVA) Satu Arah Terhadap Kekuatan Tarik Serat Pelepah Lontar dengan Perlakuan Alkali 5\% NaOH selama 0 menit s/d 300 menit

\section{Anova: Single Factor}

SUMMARY

\begin{tabular}{|ccccc|}
\hline Groups & Count & Sum & Average & Variance \\
\hline F max & 11 & 234,5225 & 21,32023 & 19,45163 \\
Tegangan Tarik & 11 & 4422,087 & 402,0079 & 1443,634 \\
\hline
\end{tabular}

ANOVA

\begin{tabular}{|ccccccc|}
\hline $\begin{array}{c}\text { Sumber } \\
\text { Keragaman/Varians }\end{array}$ & $S S$ & $d f$ & $M S$ & $F_{\text {hitung }}$ & P-value & $F_{\text {critis }}$ \\
\hline Antara group & 797077,3 & 1 & 797077,3 & 1089,584 & $6,43 \mathrm{E}-19$ & 4,351243 \\
Dalam group & 14630,85 & 20 & 731,5426 & & & \\
Total & 811708,1 & 21 & & & & \\
\hline
\end{tabular}

Dari hasil analisis varian satu arah, diperoleh nilai $\mathrm{F}_{\text {hitung }}>\mathrm{F}_{\text {critis }}$, maka dapat disimpulkan bahwa perlakuan alkali $5 \% \mathrm{NaOH}$ selama 240 menit menyebabkan terjadinya peningkatan sifat mekanis (kekuatan tarik) serat pelepah lontar.

\section{SIMPULAN}

Dari hasil penelitian yang dilakukan, maka dapat ditarik suatu simpulan bahwa 1 ama waktu perlakuan alkali terhadap serat pelepah lontar mempengaruhi nilai kekuata $\mathrm{n}$ tarik yang dihasilkan. Berdasarkan data hasil pengujian serat pelepah lontar, kekuatan 
tarik yang paling maksimum dimiliki oleh serat pelepah lontar dengan perlakuan alkali 240, ini juga didukung oleh modulus elastisitas serat pelepah lontar yang diberi perlakuan 5\% $\mathrm{NaOH}$ mengalami peningkatan pada waktu perendaman serat selama 240 menit dan setelah lebih dari 240 menit maka terjadi penurunan modulus elastisitas. Hal ini menunjukkan bahwa perlakuan $5 \% \mathrm{NaOH}$ merupakan perlakuan yang paling efektif untuk meningkatkan kekuatan tarik serat pelepah lontar, namun jika perlakuan $\mathrm{NaOH}$ terlalu lama maka regangan mengalami penurunan. Meskipun pada titik tertentu terlihat ada peningkatan tetapi secara umum trendnya cenderung menurun

\section{UCAPAN TERIMA KASIH}

Ucapan terima kasih penulis sampaikan kepada Politeknik Negeri Kupang melalui Dana DIPA yang telah mendanai penelitian ini .

\section{DAFTAR PUSTAKA}

[1] Badan penelitian dan pengembangan kehutanan kementerian kehutanan. Lontar (Borassus Flabellifer) sebagai sumber energi bioetanol potensial,2010

[2] Callister, W. D. Material Science and Engineering an Introduction, John Willey and Sons Inc, New York, 1991.

[3] George,Dana. What is the Function of Cellulose? http://www.ehow.com/about_4673591_What-Function-Cellulose.html. Diakses 22 Pebruari 2011.

[4] Gibson, F.R., Principles of Composite material Mechanis, International Edition", McGraw-Hill Inc, New York, 1994

[5] Harper, A. C., Handbook of Plastics, Elastomers and Composites, 1996

[6] Jacobs, J.A. Kilduft T.K. Engineering Material Technology Structure, Processing, Property and Selection 2. Prentice Hall,Inc A Simon Schuster Company, USA, 1994.

[7] Lempang ,M. Asdar,M, dan Limbong,A. Ciri anatomi, sifat fisis dan mekanis, dan kegunaan batang lontar. Jurnal Penelitian Hasil Hutan Vol. .27 No.21 ,Maret 2009, 38 $-52,2009$.

[8] Lutony, T.L. Tanaman Sumber Pemanis . PT. Penebar Swadaya ,Jakarta. Hal.:113-120, 1993.

[9] Mahmud,Z dan Amrizal. Palma sebagai bahan pangan, pakan dan konservasi . Buletin Baltika No.14:106-113 . Balai penelitian kelapa, Menado, 1991

[10] Mahmud, Z., Allorerung D dan Amrizal. Prospek tanaman kelapa, aren, lontar dan gewang, untuk menghasilkan gula. Buletin Balitka No. 14 Thn. 1991 hlm. 90 - 105. Balai Penelitian Kelapa. Manado,1991

[11] Saragi,Deli Natalia. Pembuatan dan Karekterisasi Genteng Beton yang Dibuat dari Pulp Serat Daun Nenas-Semen Portland Pozolan. Tugas Akhir. Fakultas Matematika dan Ilmu Pengetahuan Alam. Universitas Sumatera Utara, 2007

[12] Smith, W.F.. Priciples of Materials Science and Engineering, $2^{\text {nd }} e d$, Mc Graw-Hil, Singapore, 1996

[13] Surdia, T. Saito, Pengetahuan Bahan Teknik, Edisi ketiga, PT. Pradnya Paramita, Jakarta, 1995 .

[14] Surdia,T., Pengetahuan Bahan Teknik, Pradnya Paramita. Jakarta, 2000

[15] Vallo Claudia, Jose M. Kenny, Analia Vazquez and Viviana P. Cyras Reinforced with Sisal Fibre Effect of Chemical Treatment on the Mechanical Properties of Starch-Based Blends. Journal of Composite Materials 2004; 38; 1387. DOI: 10.1177/0021998304042738, 2004. 